패 -15882

SERIES AND COPY NO.

\section{GEMERALO ELETMIC}

HANFORD ATOMIC PRODUCTS OPERATION - RICHLAND, WASHINGTON TITLE

RESTRICTEU DATA

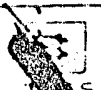

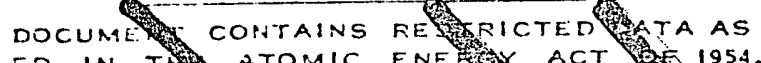
DI TED IN TH ATOMIC ENEWT ACT 1954

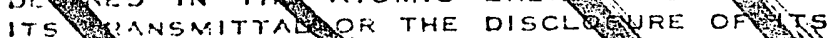

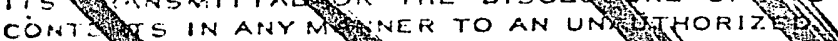
PCRSONA PHOHIEITA

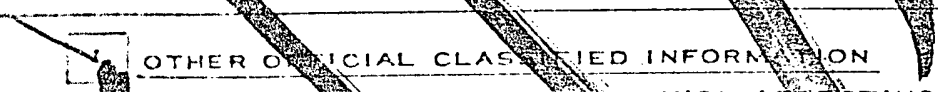

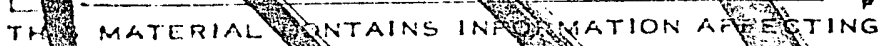

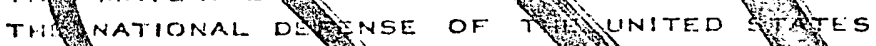

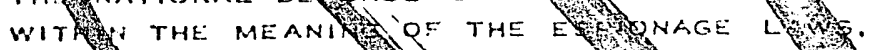

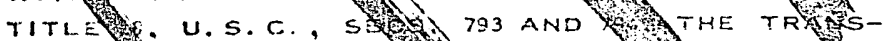

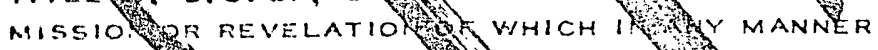

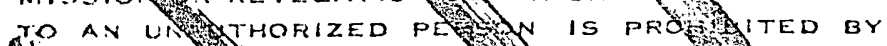 an.
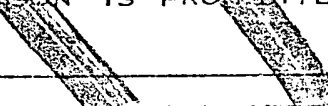

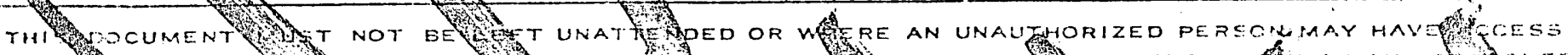

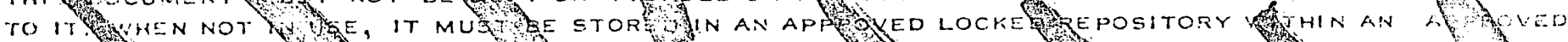

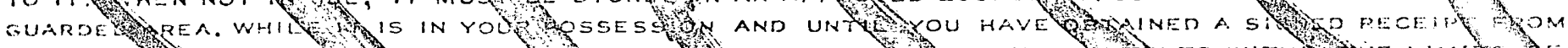

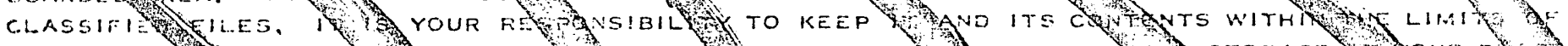

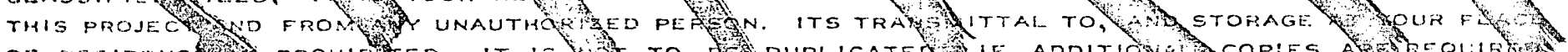

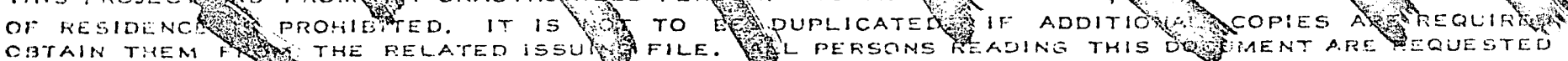

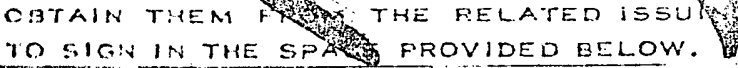

ROUT: TO:

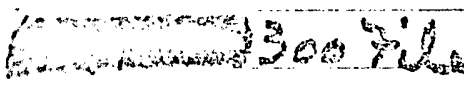

AUTHOR

HA Kramer
A Study of the Effects of a Disaster at Grand Coulee Dam Upon the Fanford Works

PAYROLL NO.

LOCATIOHA

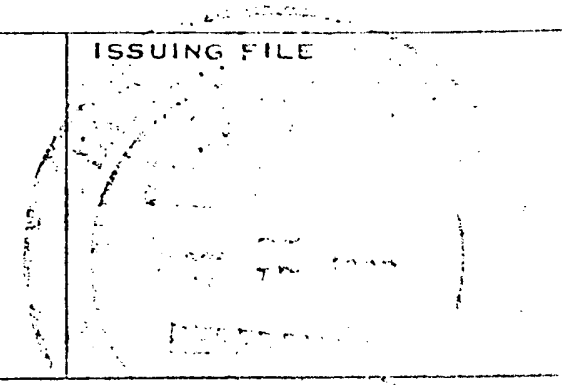

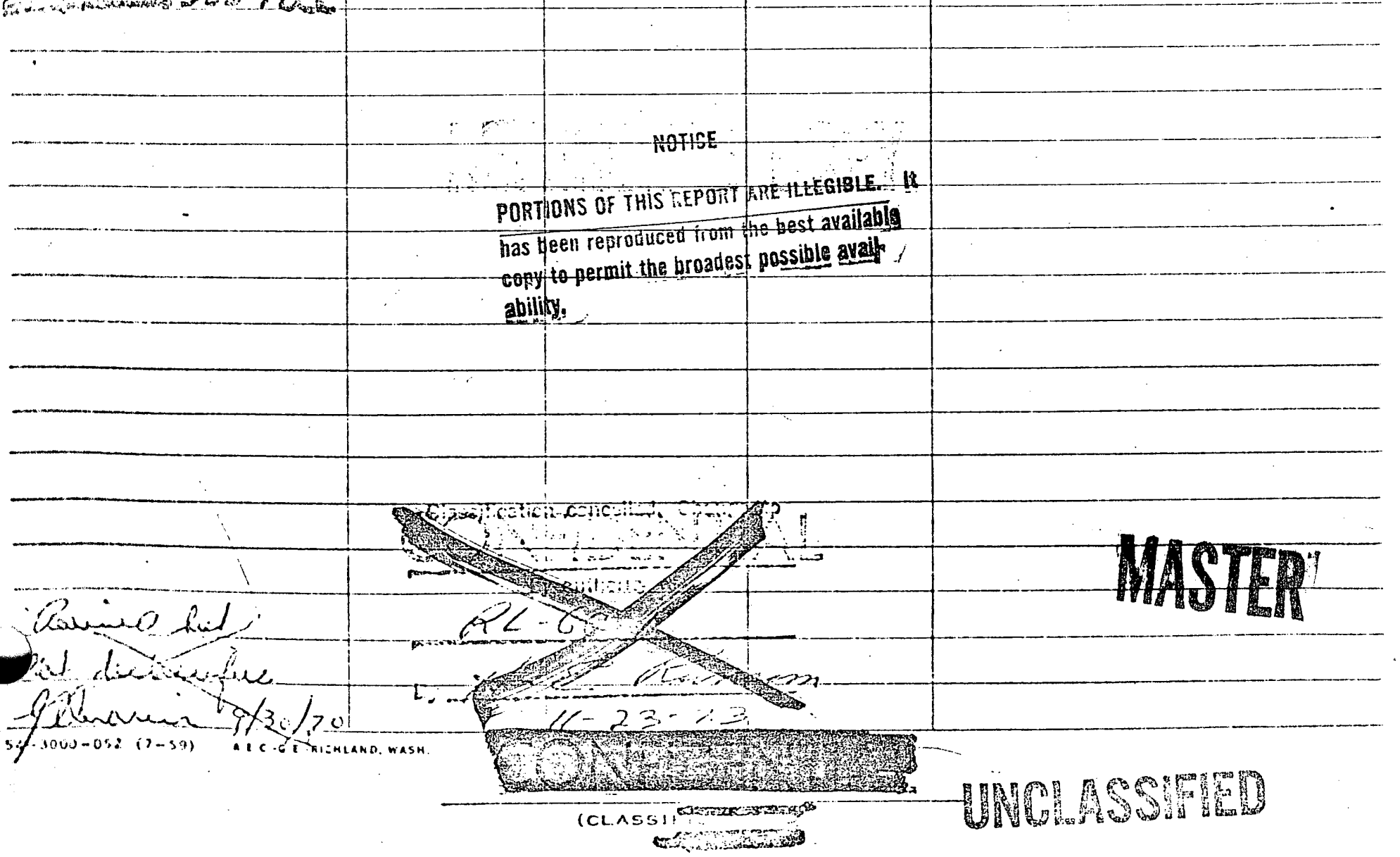




\section{DISCLAIMER}

This report was prepared as an account of work sponsored by an agency of the United States Government. Neither the United States Government nor any agency Thereof, nor any of their employees, makes any warranty, express or implied, or assumes any legal liability or responsibility for the accuracy, completeness, or usefulness of any information, apparatus, product, or process disclosed, or represents that its use would not infringe privately owned rights. Reference herein to any specific commercial product, process, or service by trade name, trademark, manufacturer, or otherwise does not necessarily constitute or imply its endorsement, recommendation, or favoring by the United States Government or any agency thereof. The views and opinions of authors expressed herein do not necessarily state or reflect those of the United States Government or any agency thereof. 


\section{DISCLAIMER}

Portions of this document may be illegible in electronic image products. Images are produced from the best available original document. 


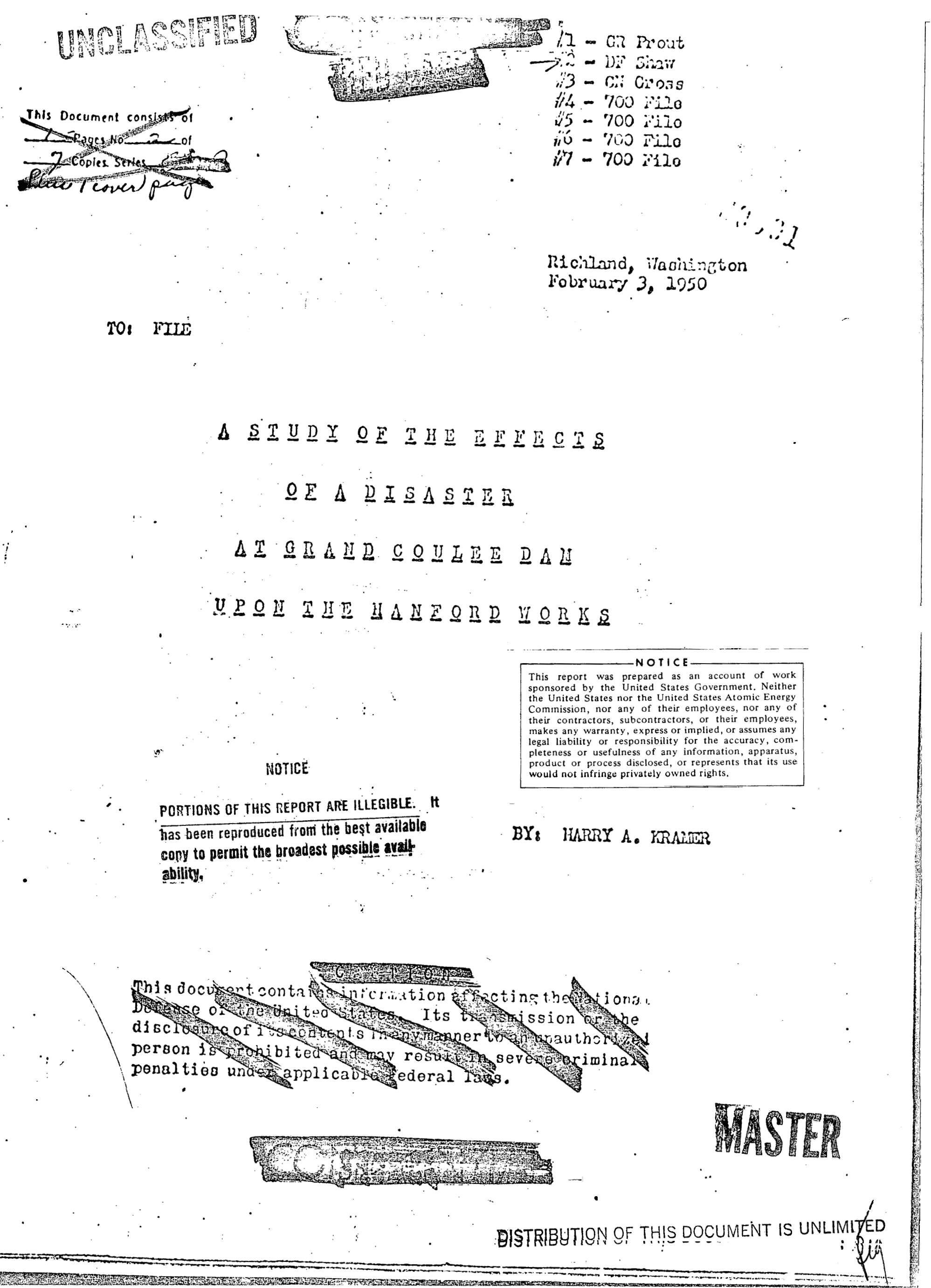


I I D

$$
-\infty 00
$$

Pagea

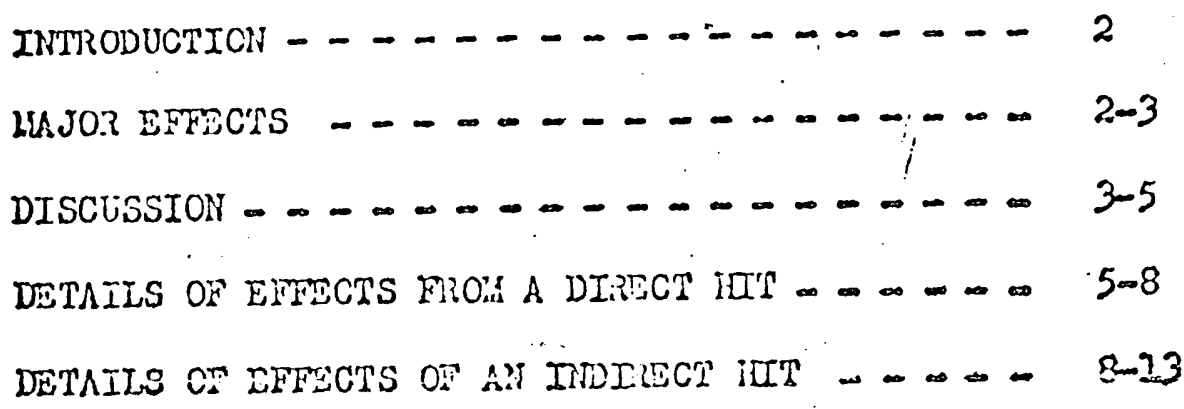

CURVES $\infty+\infty \infty_{\infty}+\infty \ldots+\infty \ldots+\infty$

$$
-\infty 00
$$

$-1$ 
The folloring data shoils the oifect of a disastor at Grand Coulco Dan upon tho llanford irorks.

Thlo study wa mado at tho ronuest of the Hanfard iiorka Dasabtor Oawn t too.

Tho basis upon which she study was mado and tho nothocis involvod aro oxplainod in tizo study.

It 1s calculatod thet tho possible sperturo îna a sinelo atoinio bomb explosion wo Id aprarimato 137,000 squaro ieot. Actial. destruction of German dians was stuiciud by ii. I. Bonin of tiro Atanio Enorgy Conmasion. 'i"ieso siucidos indicato tino vulnoravility of tho dan and tho possibilituy ot the aboso mentionod danafo. jor oonvonionco and for inoremontial dostruction data, tiro abovo aportura ras also studied as threo trapozolaal oponings of total oquivalont ex"ea,

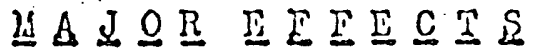

\section{ASETISTICUis:}

It Is assured that an atonic bano on other explosivo rould bo so dotonated that tho dan rould so dostroyed, or thit tho rosulting break rould be equivilent in proportion to dam banb dostruction In Vorld var II of the German Dans (iho Lionno Dan, Tho lider Das, and others), winich wore destroyad by tho British.

The prosent atomic bomo has more than doublo tho nocoseary oxplosive forco required. Thorefore, the sliccosoful destruction of the dam by. a properly dosicnod boinb is prodicated only by a voli onginocrod placement of the focal point and by tho rosistanco to such an attack.

\section{EFIECTS:}

- ASSU:YYION Ono diroot hit.

\section{DNIACEN}

1. Ono-half Richland Foodod.

2. Ludray Subotiation Inundatod.

3. Richland Loolatod.

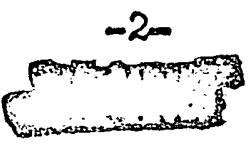




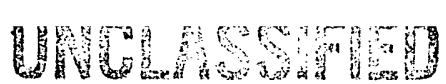

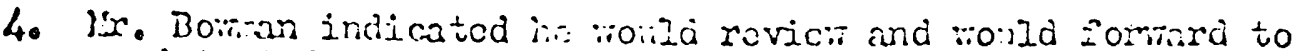

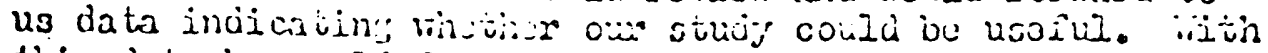
this data he rould inomal his comants on the inioniation wo had colloctod as to cyplosivo oijects.

5. Thooe cammonis and cxplosivo eifect data havo just beon recoived. They inaicüto:

a. Grand Coulco Das is vinerablo.

b. Ho surizeoto tino iminodato cevuloprnont of jour on isoro Intemediate däus betiieen llanîna and Grana Couloo.

Tho attachod skotchos Fero doveloped by making soveral basic assuintionss

2. Tho offect of a drect ilit on Grand Couloo Dam by an ajomic banb roild bo the equivaicnt oi thrce openings 20 'r scet long at the top, 250 Icet deep, and 100 Icet ride at tho bottan. The main dan is 1,650 Loo iong, the total longth is approimately 4,200 seot.

2. Roosovelt Lake rould bo full $\left(I, 290\right.$ feet $\left.2 L_{0} S_{0} I_{0}\right)$.

3. Laximura flood flor (725,000 c.f.s.).

4. Tho river between Grand Couleo and tho Ilaniford Works Would bo recoiving an adciitional 75,000 cos.s.

5. Interricdiato calculations rero based on nomal river conditiona.

6. No cnglnecrino data is published corving the trapezoicial openings described, sinco tise discharge will submerge the notcires. Tho method recomonded in Tabie 128 , page $1640 \hat{i}$ Kings Handboo: was used. (Peak illors will jo slifintly belor the rifures sinom in attached sheots and olevations slichtigy Iorrer.)

7. Whon and if Wcivary Darn is in oporation, they will bocin IorrerIng tho pool at Richlana within a foir mononts aiter tho Couleo
destruction.

8. The flood routing motinod used is doscribed on pares 147 to 156, inclusive, Flood Contro? ?anunl, Font Belvoin, X156. inis is

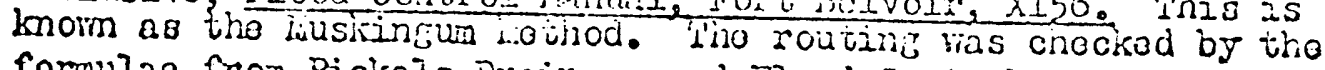
formula from Pickols Diainace and Flood Contiol.

$$
\frac{I_{1}+I_{2} t}{2}-\frac{O_{2}+O_{2}}{2}=s_{2}-S_{1} \text { Eto. }
$$

The fifcures from the juslingur lothod rere used since tho wothod ovaluatos both vedge and primatio storage in the reach. 
It is a lault of tilig notiod wat initial ivisos on tis

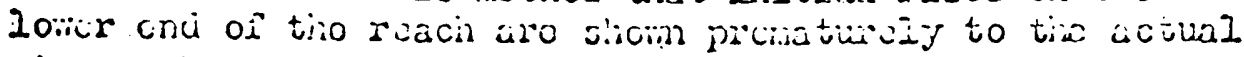

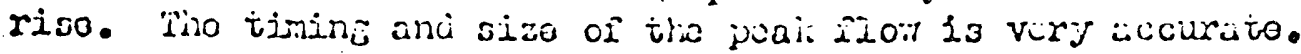

9. Toporraphy of river cizannels at oach simificant annioid

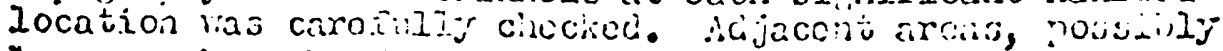

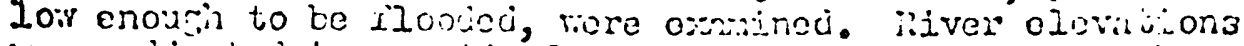
Fero adjusted to provids ior pooling oifecto or channol ridoning.

10. Intormodiato data ras socured ug carrapolation.

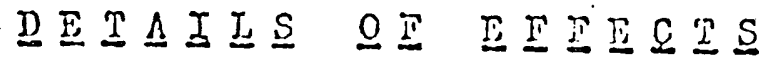

EIIIA DIRECI III

1. Grand Couloo Dam Is vulnerable to Atomic Bonb attack. Dam Data

Iength - 4,.273 (Concrote)

Base Vidith -500 foot

Depth to Bea i:ock on 550 seot

iop Vidth - 30 jeat

Proper Bepth for successful bomb - 370 feot

Propor Distanco aoovo Dan - 00 Ieat to 270 soot

2. A disect hit ircuid causs destruction that wouid result in a rivor riso at Riohland in 8 to 12 hours.

3. The meximun rater elovation at irichland would approximato:

387 feot 2I.S.L.

\pm 2 feot.

357.I foot IS.S.I. - I948 IJood Peak

40:. The maxtmu rater elevation at $200-B$ rould approxinate:

452 feet lu. S.I.

\pm 2 root

Butláing olovations - 100-B: 1

181 Building

182 Builàin:

283 Building Pun Room Foor

184 Building Stcas Plant

185 Builuidng

230 Builaing

Vaste lietontion isasin

Top of iiall

205 Building

427 foot is.S.Iso

442 foot i.s. S. .

440 seot in.s. I.

453 foot i.S.I.

467 200t Lis.s.

467 feet is.s.L.

442 I7" H.S.L.

469 seot ís.s. I. 


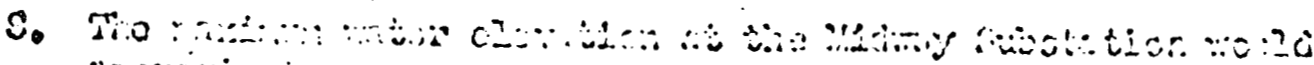
arjocion:

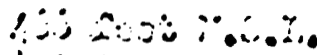

$$
\begin{aligned}
& \text { + }
\end{aligned}
$$

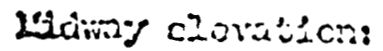

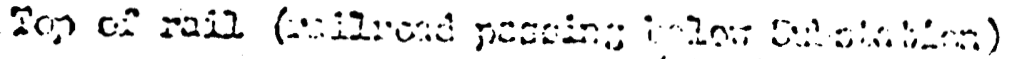

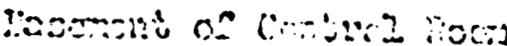

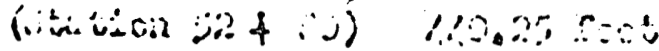

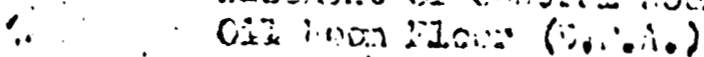

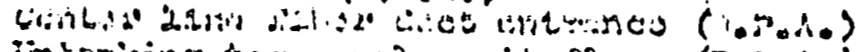

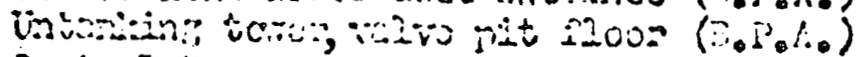

$$
\begin{aligned}
& \text { Conibrol i:002 izbos }
\end{aligned}
$$

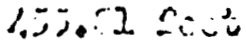

$$
\begin{aligned}
& 1950.15 \text { Sordi } \\
& \therefore 10 \therefore \text {. } \\
& 10.0 .32004 \\
& \text { lision }
\end{aligned}
$$

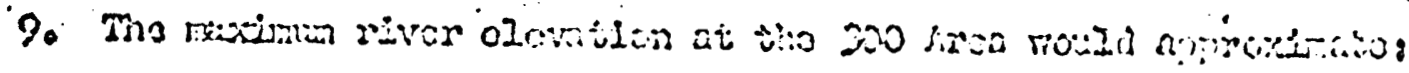

$$
\begin{aligned}
& 1.05 \text { seot } \because 05.20 \\
& 25 \text { scot }
\end{aligned}
$$

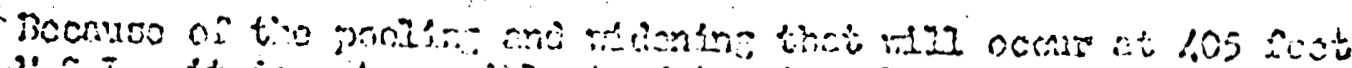

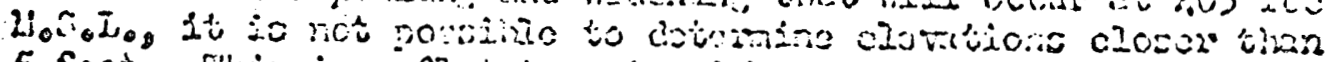

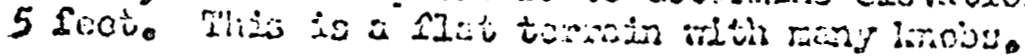

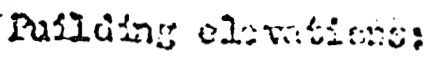

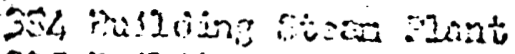

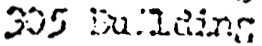

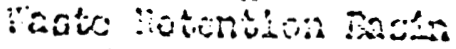

$$
\begin{aligned}
& \text { 20p of ris: }
\end{aligned}
$$

300 ant :

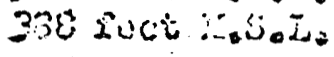

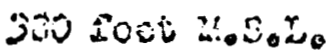

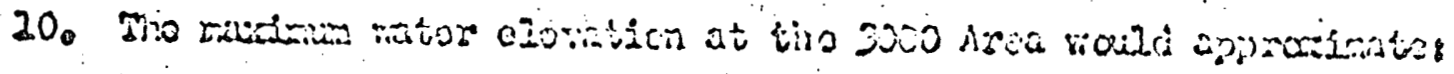

$$
\begin{aligned}
& 103 \text { riot } 2 x_{0} r_{0} L_{0} \\
& 25 \text { I00t }
\end{aligned}
$$

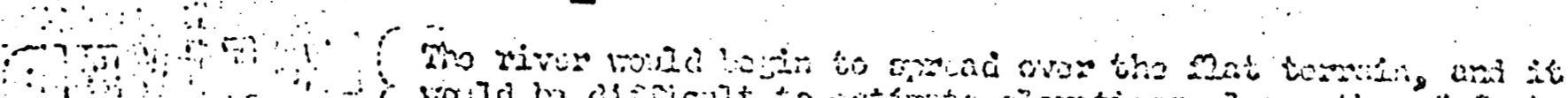

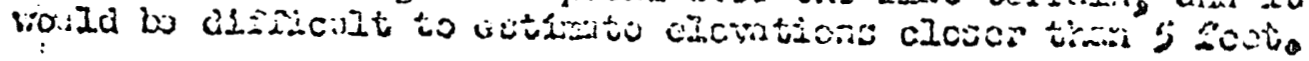

\section{Richingu cfsccts:}

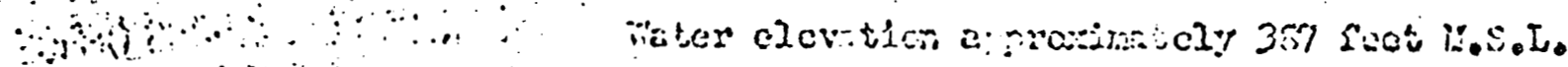
and

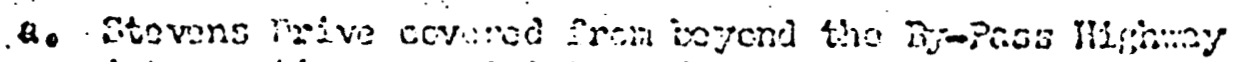

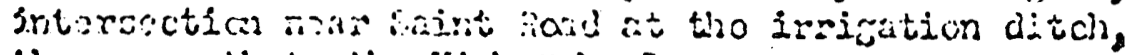

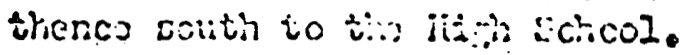

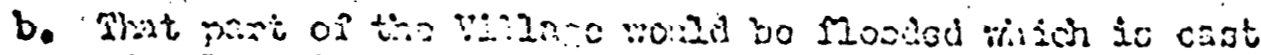

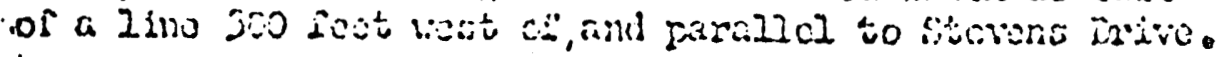

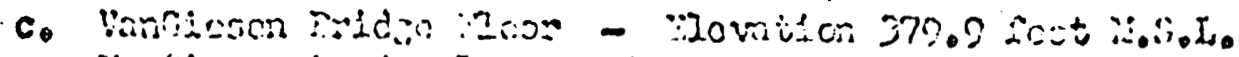

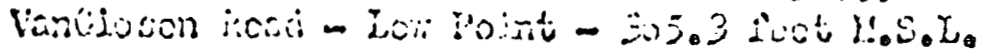

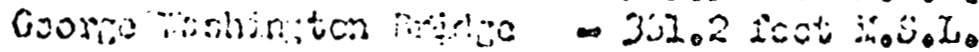

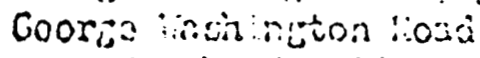
siritis of 2 iasing - 350.5 Sot i. 
d. lospitis clevation Adتinistation Bailain; 703 Rocreation iball icsi intrance Irangiont Guartere isascioni
362.2 scot ?... S.I.

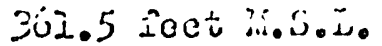
375.1 foct i.. S.L. 300.6 soot L.S.L.

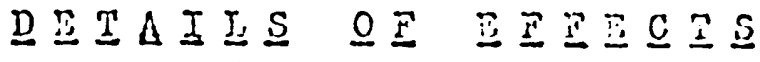

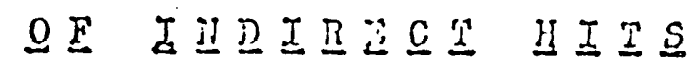

It 10 bollovod that ono poorly illacod boab might broach an opening equivalent to ons notch; tro, tiiio notcinos, cio.

Piadicted Mator Tilovation Pent is Se Ie

100-B $\therefore$ Bomb Effect

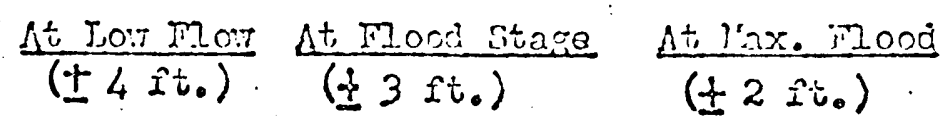

I Notch

2 llotches

Diroct ilit (3 llotches

(Complo to Failure

423

429

431

432

200-D

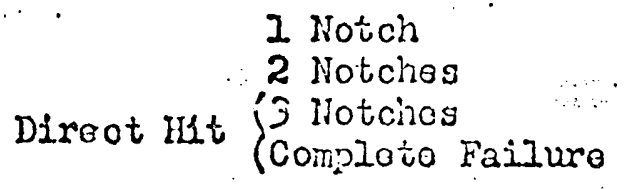

421

417

429

420

$200-F$

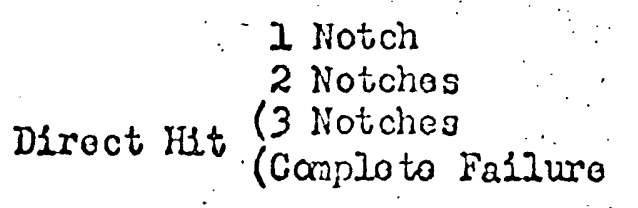

398

404

406

407

$200-\mathrm{H}$

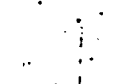

2 Notch

2 Notches

Drroct Hit (3 Notchos

(Completo Pailura

300 Arca

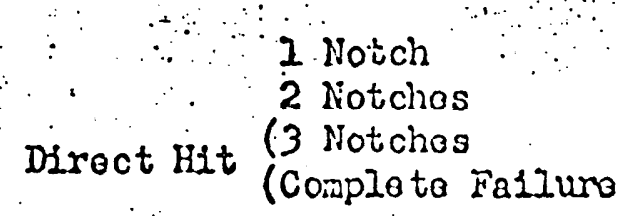

338

403

409

421

422

438

443

444

446

449

447

451

452

426

432

434

435

432

437

439

440

423

419

421

422

426

427

392

394

395
423

429

431

433 
Bichlind

Banin nerect

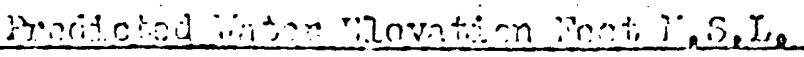

\begin{tabular}{|c|c|c|c|c|}
\hline Direot Hit & 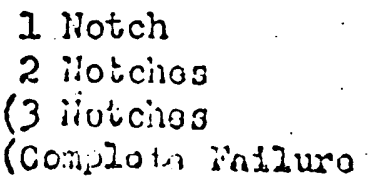 & $\begin{array}{l}373 \\
377 \\
300 \\
362\end{array}$ & $\begin{array}{l}379 \\
333 \\
335 \\
306\end{array}$ & $\begin{array}{l}300 \\
304 \\
300 \\
387\end{array}$ \\
\hline
\end{tabular}

2 Notch o Opening 267 foot rido at top, 250 foot deop, 100 fleot rido at bottox.

Notes An Indiract atoric bomb explosion is assured to be bohind tho

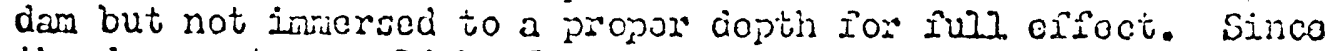
the drun gatos rould bo forcos to an oquivalont. fuzl oponing, the resulting ofiect is included above.

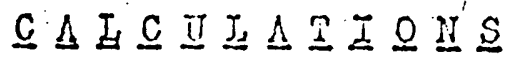

Basiar Condition beforo disastar

I/I Flood Equivalent $165 / 4$

ith Floúa stago

it3 Loir Stago

Richiand Elevation 340 soet is.S.I. Miciniand

\section{$\underline{Y} \underline{P} \underline{E}$ IISA $\underline{I} E R$}

1. Ons indirect hit atconic bovio.

2. Tho Indirect hits atonic bomb.

3. Throo indirect hits atonic bario.

4. Direct hit atonic basib.

An Indirect hit is assumed to erfect a trapozoidal opening 267 feot long at tho top, 250 leot coop and 100 feet widio at tho bottan.

Complets failure is olightly moro than throo indiroct hits.

An. Indirect hit is a banb exploding wo that tho full of rect rill not be obtainod. It is equivalent to onemsisth of tro present banb forco. 
EI QII I IIOIEII OPEUIIGS

KIng's Formula, pago 264 ,

$$
z=1 / 3 \quad b \quad b=200
$$

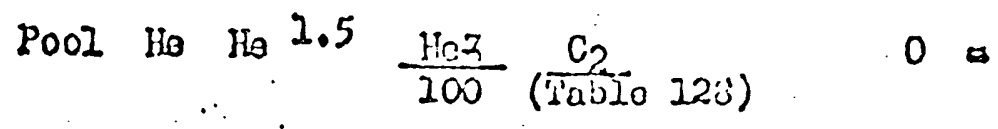

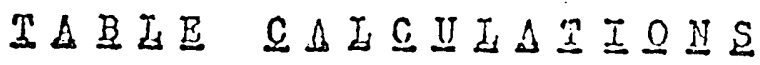

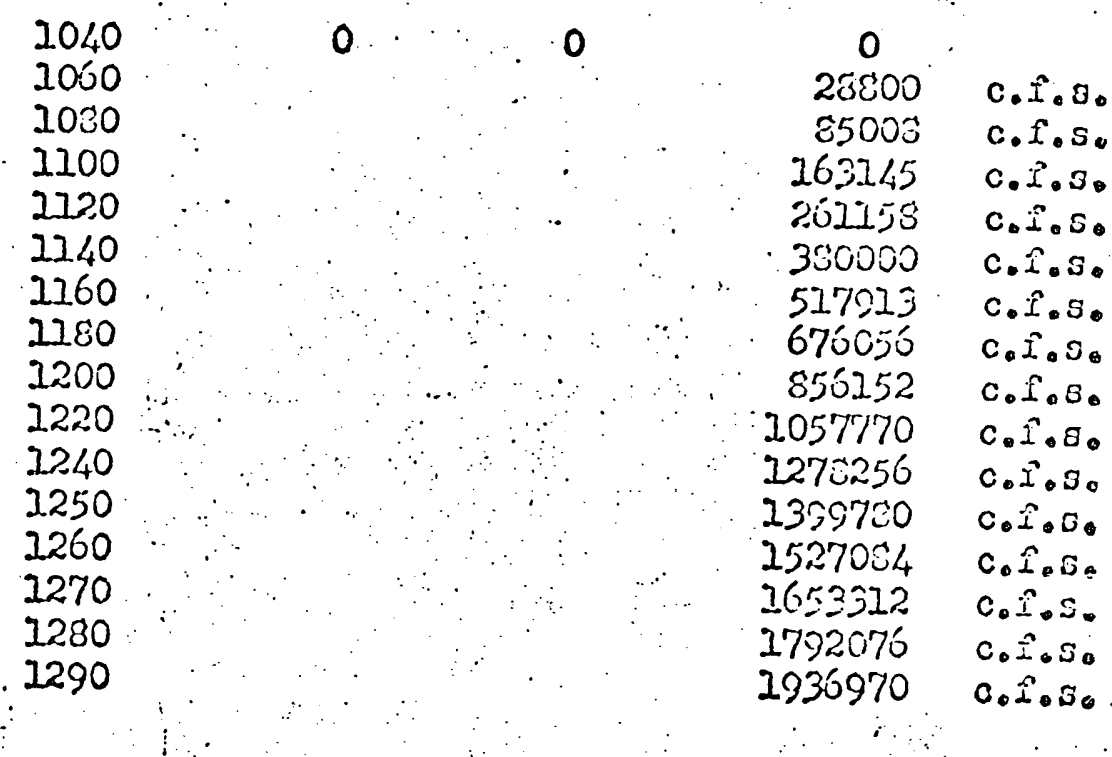

The routing timo through Roosovelit Lalke - 6 hours Routing forralus

$$
\text { II }=\frac{T\left(0.5\left(i_{2}+i_{1}\right)-0.5\left(d_{2}+d_{1}\right)\right.}{X\left(i_{2}-i_{1}\right)+\left(I_{1} 0-i\right)\left(d_{2}-d_{1}\right)}
$$




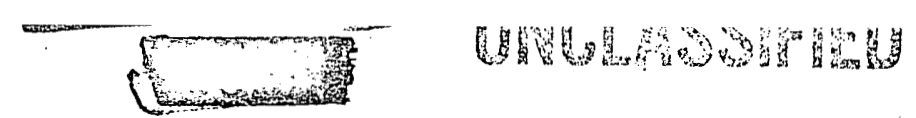

Jiatural Discisaro

Coulco

iliohland

725000 C...... 800000 c. ...

ELEVATIOI $\triangle I D$ IIUU

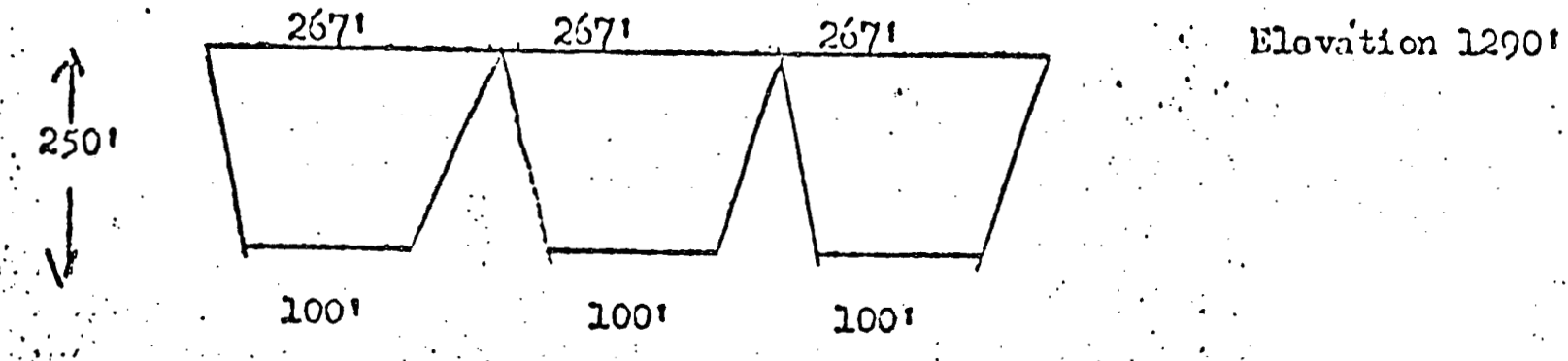

1,650,000 c.foso Each Notch
2,000,000 c...s. Loss of Drim Gates

Bydraultc itave

Tota? 12.07

Incitary

$1,000,000$ c.f.s. $\quad 1,000,000$ c. $\hat{x}_{0} s_{0}$

Lose of Drum Gatos

1 Notch

2 Notches

3 Notches

Comple te Fallure

Hydraulic iiave

Loss of Irum Gates

1 Notch

2 Notches

3 Notches

Comploto Falluro

$$
\begin{aligned}
& \text { 1,720,000 c.5.s. } 1,032,000 \text { c. ...5. } \\
& \text { 2, ZIÜ, 000 c.i.s. 2,250,000 c.f.s. } \\
& \text { 2, 450,000 c.f.s. } \quad 2,627,000 \text { c...... }
\end{aligned}
$$

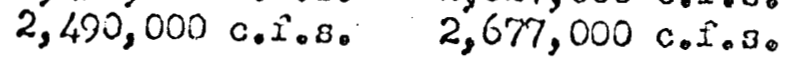

Incrosso ontr

$$
\begin{aligned}
& 275,000 \text { c.f.s. } \\
& 720,000 \text { c.s.s. } \\
& \text { 2,210,000 c. ...s. } \\
& \text { 1, 450,000 c.1.s. } \\
& \text { 1, 490,000 0.2.s. }
\end{aligned}
$$

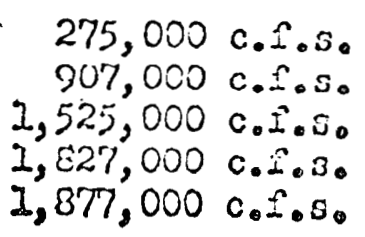

\section{$\frac{7450}{1827}=\frac{2270}{x_{1}}=\frac{720}{x_{2}}$}

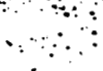

$\therefore$

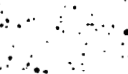

.7937 
EEQIII I HQ OUG

One opening - 2,650,000 c.î.s. at Grand Couleo

Routud fras Grand Couloo to tho ianford vorles, tho flood offect of ino oponine rould be:

\section{Mogdimy Pinect}

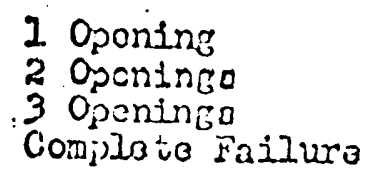

$$
\begin{aligned}
& 907,000 \text { o. . .s. } \\
& 1,525,000 \text { c.1.0. } \\
& \dot{i}, 027,000 \mathrm{c.} . \hat{\mathrm{i}} \mathrm{s} \\
& \vec{i}, \delta 7 \%, 000 \text { c.s.s. }
\end{aligned}
$$

At Jorr Roir otage river elevation at Riciland:
1 Oponing
2 Openings
3 Oponings
Complete Failure

$$
\begin{aligned}
& \text { 94:4,000 cô.s. } \\
& \text { 1,562,000 c.5..s. } \\
& 1,864,000 \mathrm{coi} \cdot \hat{1}_{0} \\
& \text { 1,904,000 cos.os. }
\end{aligned}
$$

At flood stage of river elovation at Richland:
1 opening
2 oponings
3 openings
Comple to Faliuro

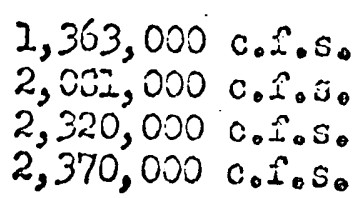

St oquivalont 1894 flood at Richland:
1 Opening
2 Openings
3 Openings
Complato Failuro

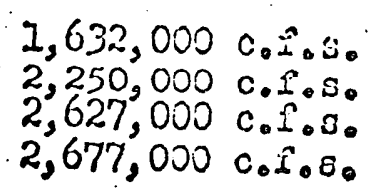


Completo Piluro

Ta1] R180

Natural Fow

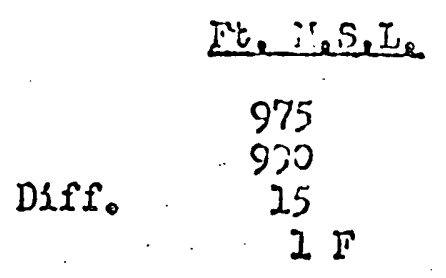

725,000 c. $f_{0} .5$. 610,000 c.i.j. 275,000 c.s...
W.0:7 ceses

395,000

610,000

225,000

24,334
9931

9901

802 ?.

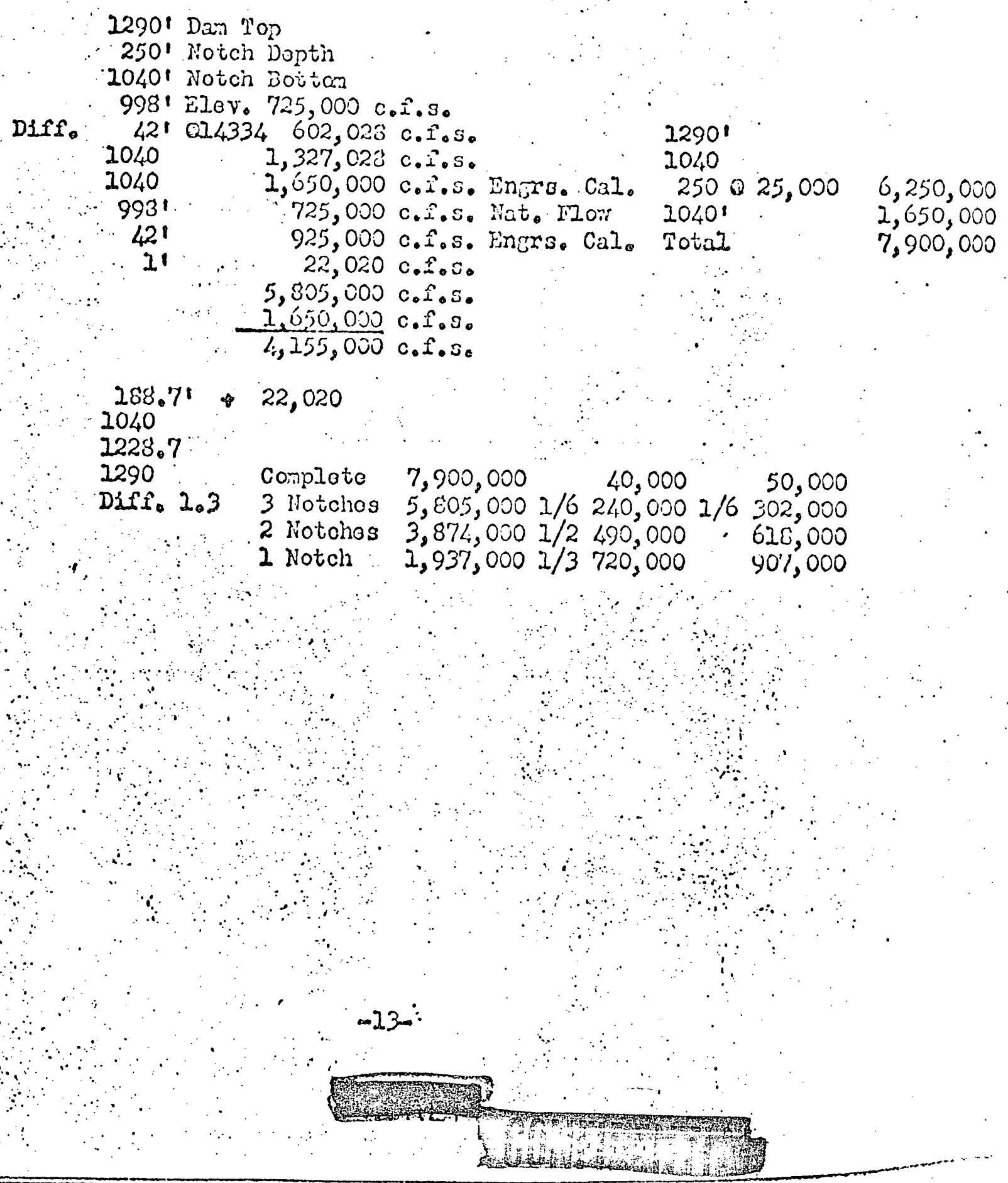

2290 Dam T'op

2501 Notch Doptin

10401 Notcin Bottom

9981 LIev.725,000 c.去.s.

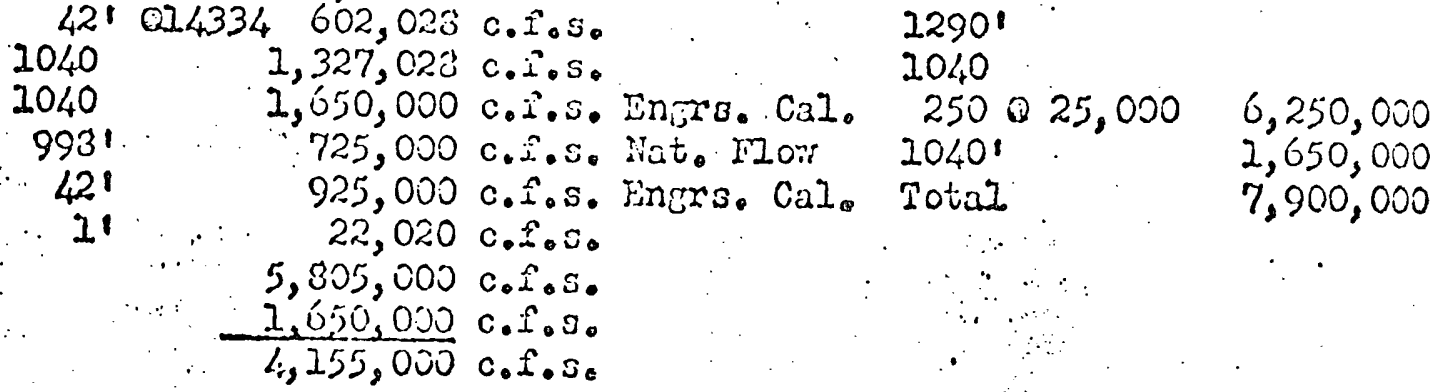

$\begin{aligned} & 288.7 \% \\ & 2040 \\ & 1228.7\end{aligned} \quad 22,020$

1290 Complete 7,900,000 40,000 50,000

3 Hotchos 5,805,000 I/6 24,0,000 1/6 302,000

2 riotohos $3,874,0001 / 2490,000 \cdot 616,000$

1 Notch $1,937,000 \mathrm{i} / 3720,000 \quad 90^{\prime} 1,000$ 


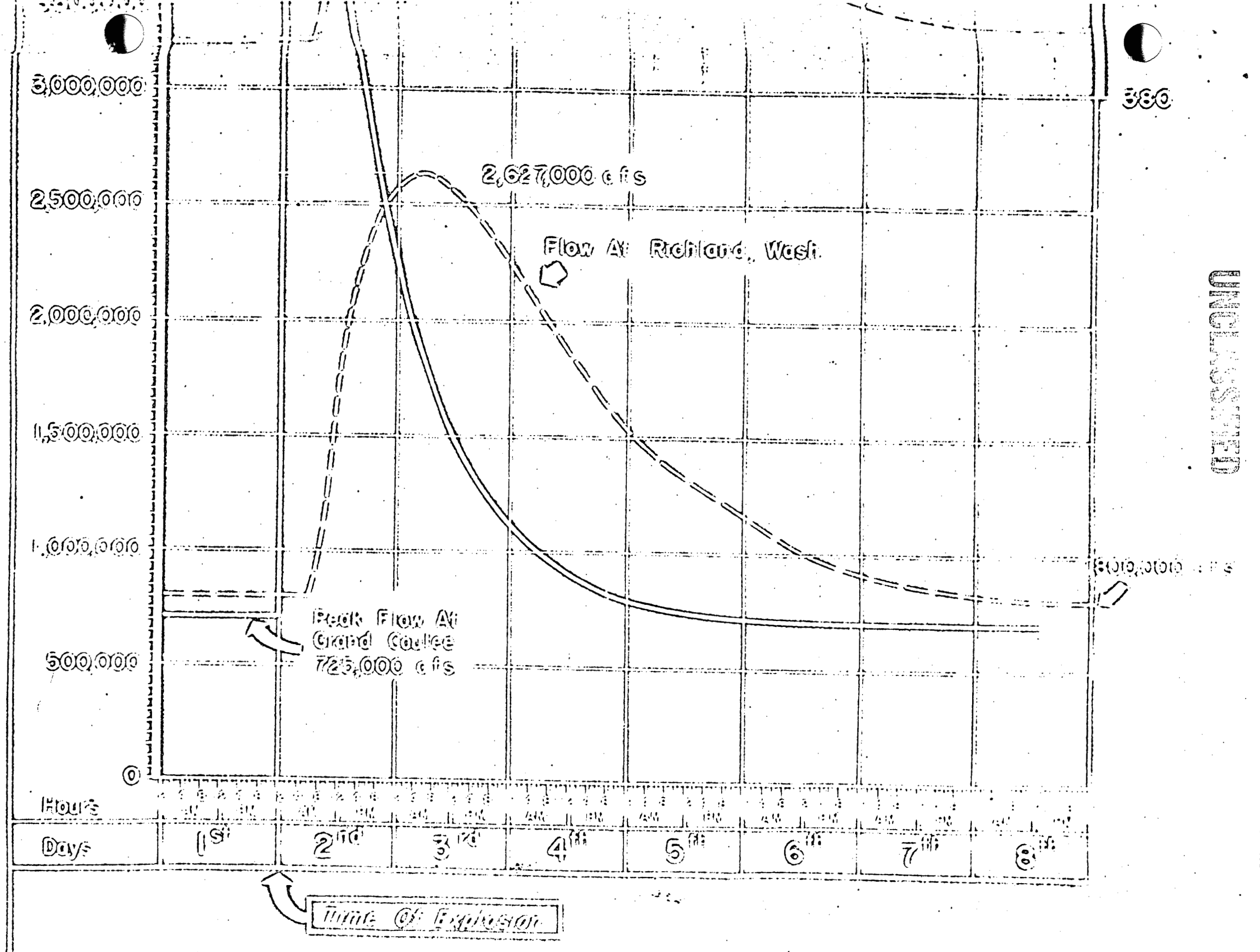

